Forestry and Grassland

Received on: 29/03/2019

Accepted on: 01/06/2020

\title{
Silage quality from intercropping corn and soybean managed with inoculant Azospirillum brasilense and nitrogen fertilization
}

\section{Qualidade da silagem do consórcio entre milho e soja manejado com inoculante Azospirillum brasilense e adubação nitrogenada}

OLIVEIRA, José Franklin Athayde ${ }^{1}$

http://orcid.org/0000-0002-0601-6607

JAKELAITIS, Adriano ${ }^{1 *}$

https://orcid.org/0000-0003-0093-9846

CABRAL FILHO, Sérgio Lucio Salomon ${ }^{2}$

http://orcid.org/0000-0003-3458-9135

SILVA, Cassio José da ${ }^{2}$

https://orcid.org/0000-0001-8558-5586

\author{
GUIMARÃES, Kátia Cylene ${ }^{1}$ \\ http://orcid.org/0000-0001-8821-9709 \\ PEREIRA, Leandro Spíndola ${ }^{1}$ \\ http://orcid.org/0000-0003-0016-0330 \\ SOUSA, Gustavo Dorneles de ${ }^{1}$ \\ https://orcid.org/0000-0003-2542-7409 \\ OLIVEIRA, Gustavo Silva de ${ }^{1}$ \\ http://orcid.org/0000-0002-9896-9156
}

${ }^{1}$ Instituto Federal de Educação, Ciência e Tecnologia Goiano -IF Goiano, Rodovia Sul Goiana, Km 01, Zona Rural, CEP: 75.901-970, Rio Verde - GO, Brasil

${ }^{2}$ Universidade de Brasília - UNB, Faculdade de Agronomia e Medicina Veterinária, Campus Universitário Darcy Ribeiro, Brasília 70910-900, Brazil

*Mail for correspondence: adriano.jakelaitis@ifgoiano.edu.br

\begin{abstract}
Intercropping grass and soybeans can promote beneficial effects on the productivity of the explored area due to the better soil nitrogen utilization and protein concentrate savings through the use of mixed silage. This study aimed to evaluate the bromatological quality, digestibility, and fermentation profile of silage produced by intercropping corn and soybean. Eight treatments were tested by combining inoculation with Azospirillum brasilense and nitrogen fertilization applied to corn intercropped in rows alternated with soybean. Corn and soybean monocultures were also tested. The morphological compositions of soybean and corn plants in the mass of the ensiled material were determined. After crushing, the material was ensiled in PVC tubes for 60 days, and the silage quality was determined after fermentation. Treatments did not affect the morphological composition of soybean and corn plants in the ensiled material from intercropping. The proportions of soybean leaves, stems, and pods represented less than $5 \%$ of the total ensiled mass of intercropping. On the other hand, the morphological composition of corn plants was high, similar to that of monoculture. Thus, the silage from intercropping showed similar quality standards to that of corn monoculture, and the
\end{abstract}


bromatological composition, digestibility, $\mathrm{pH}$, energy content, and profile of organic acids were suitable for good quality silage.

Keywords: Glycine max, Zea mays, bromatological composition, fermentation profile

\section{RESUMO}

A consorciação entre gramínea e soja pode promover efeitos benéficos sobre a produtividade da área explorada, devido ao melhor aproveitamento do nitrogênio no solo e economia de concentrados proteicos pelo uso de silagem mista. Objetivou-se neste trabalho avaliar a qualidade bromatológica, digestibilidade e o perfil de fermentação da silagem produzida pelo consórcio entre milho e soja. Foram testados oito tratamentos, combinando a inoculação com Azospirillum brasilense e a adubação nitrogenada aplicada no milho consorciado em fileiras alternadas com a soja. Os monocultivos de milho e de soja também foram testados. Foram determinadas as composições morfológicas das plantas de soja e milho na massa da matéria ensilada. Após triturado, o material foi ensilado em tubos de PVC por 60 dias e após a fermentação foi determinada a qualidade da silagem. Os tratamentos não afetaram a composição morfológica das plantas de soja e de milho no material ensilado oriundo do consórcio. As proporções de folhas, hastes e vagens de soja representaram menos de $5 \%$ do total da massa ensilada do consórcio. Por outro lado, a composição morfológica das plantas de milho foi elevada semelhante ao do monocultivo. Assim, a silagem proveniente do consórcio apresentou padrões semelhantes de qualidade ao do milho exclusivo, sendo que a composição bromatológica, digestibilidade, $\mathrm{pH}$, teores de energia e perfil de ácidos orgânicos foram adequados para uma silagem de boa qualidade.

Palavras-chave: Glycine max, Zea mays, composição bromatológica, perfil de fermentação

\section{INTRODUCTION}

Intercropping grasses and legumes is a common practice in the field because these plants present complementarity in the use of growth resources (DU et al., 2017). The use of available water, nutrients, and light resources is optimized in intercropping systems compared to monocultures (CHEN et al., 2017; BATISTA et al., 2019). In this sense, studies on corn-soybean intercropping are strategic aiming mainly at increasing the protein content in corn silage, using soybean as an accompanying crop (SANTOS et al., 2017). Furthermore, it stands out for reducing production costs by optimizing the use of fertilizers, mainly nitrogen $(\mathrm{N})$, increasing the solar radiation use efficiency, improving land-use efficiency, and providing diversified income to producers (DU et al., 2017, CHEN et al., 2017; BATISTA et al., 2019).

Corn is the main crop used to produce silage in Brazil due to its high productivity and amount of fibrous and non-fibrous carbohydrates that provide an excellent fermentation pattern (MORAES et al., 2013). However, corn silage has a low protein content, limiting its exclusive use for high-productivity animals, which require protein 
supplementation due to the higher requirements of this category. The nutritional balance of silage can be obtained by intercropping corn and soybean, which has a high protein content (SILVA et al., 2015; BATISTA et al., 2018). According to Lopes et al. (2014), the addition of soybean to the silage decreases the costs with the use of concentrate in the diet due to its high nutritional value, increasing the protein content of the silage.

Several legumes can be associated with corn to improve silage quality (SERAN \& BRINTHA, 2010). However, the advent of corn and soybean germplasms tolerant to herbicides, especially glyphosate, has increased the possibilities of cultivation between both species mainly due to the ease of weed control (CARDOSO et al., 2019; MARQUES et al., 2019). Information about the management of soybean-corn intercropping in Brazil is scarce, mainly related to new crop arrangements and proportions of mixtures. One of the measures used in intercropping grasses and soybean is the formation of crops in interspersed rows or strips, with the possibility of making various crop arrangements, according to the convenience and equipment available for sowing and harvesting (BATISTA et al., 2019).

Corn is a demanding plant that responds to $\mathrm{N}$ application with significant increases in production (CRUZ et al., 2008). However, the crop productivity depends on the characteristics inherent to the hybrids, edaphoclimatic conditions, soil N supply, phytotechnical crop management, and the applied $\mathrm{N}$ doses (LANA et al., 2009).
According to Sanginga \& Woomer (2009), the intercropped cultivation of corn and legumes such as cowpea, bean, soybean, and peanut accumulate from 80 to $350 \mathrm{~kg}$ of $\mathrm{N}$ and help to maintain and improve soil fertility. The use of Bradyrhizobium strains in soybean monoculture was able to replace completely the use of nitrogen fertilizers and contributed to its expansion to the Brazilian Cerrado (MENDES et al., 2008). Nitrogen fertilization through the supply of $\mathrm{N}$ available to plants has influenced the productivity of crops and their interaction with microorganisms that fix N, such as Bradyrhizobium in soybean and Azospirillum in corn, affecting their productivity. Young et al. (2015) stated that $\mathrm{N}$ use efficiency in systems that intercrop corn and soybean was improved by the interspecific transfer of $\mathrm{N}$ from soybean to corn.

In this context, this study aimed to evaluate the bromatological composition, digestibility, and profile of organic acids in the fermentation process of corn silage with soybean as a function of the nitrogen fertilization management and inoculation with Azospirillum brasilense.

\section{MATERIAL AND METHODS}

The research was conducted from December 2016 to June 2017 at the Federal Institute of Goiás, Rio Verde, Goiás, Brazil, located at the geographical coordinates $17^{\circ} 48^{\prime} 67^{\prime \prime} \mathrm{S}$ and $50^{\circ} 54^{\prime} 18^{\prime \prime}$ $\mathrm{W}$, with an altitude of $754 \mathrm{~m}$. The climate is Aw according to the Köppen classification, characterized as warm and humid, with average annual precipitation from 1500 to $1800 \mathrm{~mm}$ and average annual temperatures from 20 to $35^{\circ} \mathrm{C}$. 
The experiment was set up on an Oxisol, which had the following characteristics in the 0-20 cm layer: $\mathrm{pH}\left(\right.$ in $\left.\mathrm{CaCl}_{2}\right)=$ 5.30; $\mathrm{P}=13.1 \mathrm{mg} \mathrm{dm}^{-3} ; \mathrm{K}=181 \mathrm{mg}$ $\mathrm{dm}^{-3} ; \mathrm{Ca}=4.64 \mathrm{cmol}_{\mathrm{c}} \mathrm{dm}^{-3} ; \mathrm{Mg}=2.50$ $\mathrm{cmol}_{\mathrm{c}} \mathrm{dm}^{-3} ; \mathrm{Al}=0.04 \mathrm{cmol}_{\mathrm{c}} \mathrm{dm}^{-3} ; \mathrm{OM}$ $=3.20 \mathrm{~g} \mathrm{dm}^{-3}$; base saturation $=62.80 \%$; $\mathrm{Cu}=2.3 \mathrm{mg} \mathrm{dm}^{-3} ; \mathrm{Fe}=13 \mathrm{mg} \mathrm{dm}^{-3} ; \mathrm{Mn}$ $=59.7 \mathrm{mg} \mathrm{dm}^{-3} ; \mathrm{Zn}=4.5 \mathrm{mg} \mathrm{dm}^{-3}$; CEC $=12.1 \mathrm{cmol}_{\mathrm{c}} \mathrm{dm}^{-3}$, and particle size distribution of 645,100 , and $255 \mathrm{~g} \mathrm{~kg}^{-3}$ for clay, silt, and sand, respectively. Corn was sown at an inter-row spacing of $1 \mathrm{~m}$, reaching six plants per linear meter, with a soybean row sown between the rows, reaching 25 plants per linear meter. Sowing was carried out in the first half of November 2016. Each experimental unit was six meters wide and six meters long. Lateral rows and $0.50 \mathrm{~m}$ on both sides of the border were not used.

The experiment was conducted in a randomized block design, with ten treatments and four replications. Treatments are shown in Table 1.

Table 1. Treatments ( 1 to 8 ) referring to the corn-soybean intercropping as a function of the inoculation with Azospirillum brasilense and corn nitrogen fertilization and the respective monocultures

\begin{tabular}{ccccc}
\hline \multirow{2}{*}{ Treatments } & Inoculation with & \multicolumn{3}{c}{ Fertilization $\left(\mathrm{kg} \mathrm{N} \mathrm{ha}^{-1}\right)^{*}$} \\
\cline { 2 - 5 } & Azospirillum brasilense & Sowing & $\mathrm{V}_{4}$ & $\mathrm{~V}_{7}$ \\
\hline 1 & Inoculated & 20 & - & - \\
2 & Inoculated & 20 & 30 & - \\
3 & Inoculated & 20 & 60 & - \\
4 & Inoculated & 20 & 30 & 30 \\
5 & Inoculated & 20 & 120 & - \\
6 & Non-inoculated & 20 & 120 & - \\
7 & Non-inoculated & 20 & 60 & 60 \\
8 & Non-inoculated & 20 & 120 & - \\
\hline 9 & & Corn monoculture \\
10 & \multicolumn{5}{c}{ Soybean monoculture } \\
\hline
\end{tabular}

*Fertilizations at the phenological stages $\mathrm{V}_{4}$ and $\mathrm{V}_{7}$ were carried out in the row for Treatments 1 to 7 and broadcasted for Treatment 8 .

The corn hybrid NS90PRO2 RR (Nidera ${ }^{\circledR}$ ) and soybean hybrid M7110 IPRO (Monsoy $\left.{ }^{\circledR}\right)$ were used. The sowing fertilization in the intercropping treatments consisted of $70 \mathrm{~kg} \mathrm{ha}^{-1}$ of $\mathrm{P}_{2} \mathrm{O}_{5}$ and $32 \mathrm{~kg} \mathrm{ha}^{-1}$ of $\mathrm{K}_{2} \mathrm{O}$, and $32 \mathrm{~kg}$ $\mathrm{ha}^{-1}$ of $\mathrm{K}_{2} \mathrm{O}$ topdressed at the phenological stage $\mathrm{V}_{4}$ of corn. The sowing fertilization in corn and soybean monocultures consisted of $400 \mathrm{~kg} \mathrm{ha}^{-1}$ of 4-14-8 $\left(\mathrm{N}-\mathrm{P}_{2} \mathrm{O}_{5}-\mathrm{K}_{2} \mathrm{O}\right)$, and $32 \mathrm{~kg} \mathrm{ha}^{-1}$ of $\mathrm{K}_{2} \mathrm{O}$ topdressed at the stage $\mathrm{V}_{4}$.

Weed control was performed with glyphosate (RoundupTransorb 480®) applied at 20 days after emergence (DAE) at a dose of $2 \mathrm{~L} \mathrm{ha}^{-1}$ and a spray 
solution volume of $120 \mathrm{~L} \mathrm{ha}^{-1}$. The insecticides chlorpyrifos (Klorplan 480®) and deltamethrin (Keshet 25 EC( ) were applied at doses of 0.6 and $0.2 \mathrm{~L} \mathrm{ha}^{-1}$, respectively, and the fungicides trifloxystrobin + tebuconazole (Nativo $\left.{ }^{\circledR}\right)$ azoxystrobin + cyproconazole (Priori Xtra ${ }^{\circledR}$ ) were applied at doses of 0.75 and $0.3 \mathrm{~L} \mathrm{ha}^{-1}$, respectively.

Corn was harvested when it reached a milk line from $1 / 3$ to $2 / 3$ of the grain, while soybean was harvested when it presented the phenological stage $R_{5}$. Samples of soybean and corn plants were cut manually from the useful area using a cleaver at $10 \mathrm{~cm}$ from the soil surface, being then weighed together to obtain the yield of green matter to be ensiled. The plants harvested from the useful area were separated and divided into different parts (leaves, stems, and reproductive structures) and weighed separately to obtain the green weight. The samples were dried in a forced-air ventilation oven at $65^{\circ} \mathrm{C}$ for 72 hours to determine the dry weight of each part and obtain their proportion in the ensiled mass.

After collecting the rest of the useful area, the material was crushed and $500 \mathrm{~g}$ was taken to a forced-air ventilation oven at $55^{\circ} \mathrm{C}$ for 72 hours before the ensiling process. Then, after drying, the material was ground in 1-mm opening sieves in a Willey mill and packed in plastic bags for analysis of dry matter contents.

The experimental samples were chopped in a silage machine with a particle size of $2 \mathrm{~cm}$, placed in silos, and pressed with a density of $874.48 \mathrm{~kg} \mathrm{~cm}^{-3}$. The material was stored in experimental PVC silos measuring $50 \mathrm{~cm}$ in length and $10 \mathrm{~cm}$ in diameter. A total of $500 \mathrm{~g}$ of dry sand were placed inside the silos to evaluate losses by effluents. The silos were opened after 60 days and $500 \mathrm{~g}$ of sample were collected again and taken to dry in a forced-air ventilation oven at $55^{\circ} \mathrm{C}$ for 72 hours.

Subsequently, the material was ground in $1-\mathrm{mm}$ opening sieves in a Willey mill to perform the bromatological analysis. The analyses of dry matter (MS), mineral matter (MM), nitrogen compounds, and ethereal extract (EE) followed the specifications of the American of Official Analytical Chemists (AOAC, 1990). Moreover, neutral detergent fiber (NDF) and acid detergent fiber (ADF) were determined according to Van Soest et al. (1991). Lignin was analyzed in sulfuric acid (LDA), as described by Pereira \& Rossi Jr. (1995).

The in vitro dry matter digestibility (IVDMD) was analyzed using the methodology described by Tilley \& Terry (1963), modified for the DAISY II ruminal fermenter, following the methodology presented in the ANKOM Technology equipment user manual provided by the manufacturer.

The organic acids were determined using $25 \mathrm{~g}$ of fresh silage mixed with $225 \mathrm{~mL}$ of distilled water, which was stirred in a blender for one minute and filtered. Subsequently, $2 \mathrm{~mL}$ of the filtrate was taken and $1 \mathrm{~mL}$ of $20 \%$ metaphosphoric acid solution was added, being then frozen. The analyses of lactic, acetic, propionic, and butyric acids were performed in a Shimadzu SPD-10A VP high-performance liquid chromatograph (HPLC) coupled to ultraviolet (UV) detector with a $210 \mathrm{~nm}$ wavelength (SANTOS et al., 2011).

The $\mathrm{pH}$ was determined using $25 \mathrm{~g}$ of silage samples homogenized for 30 minutes with $100 \mathrm{~mL}$ of distilled water. 
The $\mathrm{pH}$ was read using a digital parameter.

Silage temperature was determined using a Gulton Gulterm 180 digital thermometer $\left(-30\right.$ to $\left.+180{ }^{\circ} \mathrm{C}\right)$ inserted directly into the fermented mass when the silos were opened.
The estimated values of total digestible nutrients (TDN), digestible energy (DE), metabolizable energy (ME), and liquid energy (LE) of the samples were obtained according to the equations described in NRC (2001):

$\mathrm{TDN}=\left(\mathrm{CP}_{\mathrm{D}}+\mathrm{NFC}_{\mathrm{D}}+\mathrm{NDF}_{\mathrm{D}}+\mathrm{FA}_{\mathrm{D}} \times 2.25\right)-7$

In which:

$\mathrm{CP}_{\mathrm{D}}($ roughage $)=\mathrm{CP} \times \operatorname{Exp}[-1.2 \times \mathrm{ADIP} / \mathrm{CP}]$

$\mathrm{NFC}_{\mathrm{D}}=0.98 \times \mathrm{NFC}$

$\mathrm{NDF}_{\mathrm{D}}=0.75 \times(\mathrm{NDFap}-\mathrm{ADL}) \times\left[1-(\mathrm{ADL} / \mathrm{NDFap})^{0.667}\right]$

$\mathrm{FA}_{\mathrm{D}}=\mathrm{EE}-1$

where 0.75 is the proportionality constant, 7 refers to the fecal metabolic TDN, CPD is the truly digestible CP, NFCD is the truly digestible NFC, NDFD is the truly digestible NDF, FAD is the truly digestible AF, ADIP is the acid-detergent insoluble protein, and ADL is the acid detergent lignin.

The TDN values were converted into digestible energy (DE) and metabolizable energy (ME) using the equations suggested by NRC (2001):

$\mathrm{DE}\left(\mathrm{Mcal} \mathrm{kg}^{-1}\right)=0.04409 \times \mathrm{TDN}$

$\operatorname{ME}($ Mcal kg-1 $)=1.01 \times$ DE -0.45

The conversion of TDN into net energy was performed by the Moe et al. (1972) equation, which corresponds to net energy for maintenance:

$\mathrm{NEm}\left(\right.$ Mcal kg$\left.^{-1}\right)=0.0266 \times \mathrm{TDN}-0.12$ (8)

The results were submitted to analysis of variance and the means compared by the Scott-Knott test $(p<0.05)$. Statistical analyses were performed using the software Assistat version 7.7 beta.

\section{RESULTS AND DISCUSSION}

The soybean proportion in the ensiled mass from intercropping was lower than $5 \%$ relative to corn based on dry matter, and the intercropping treatments tested for fertilization and inoculation with $A$. brasilense showed no effect on the proportions of both plants in the silage (Table 2). Only the proportions related to soybean plants in the mixture of ensiled mass from intercropping were lower compared to the monocultures, while corn had no statistical difference, showing that the coexistence of soybean with corn plants did not affect the forage yield of the morphological components of corn plants. According to Zopollatto et al. (2009), the evaluation of the structural components of corn plants is essential in the analysis of hybrids with the potential for silage production, with corn being more competitive than 
soybean when intercropped and showing no increase in the mass of ensiled matter regardless of the treatments.

Table 2. Proportions of leaves (LS), stems (SS), and pods (PS) of soybeans, tassel (TC), stem (SC), leaves (LC), cob (CC), grains (GC), and straw (StC) of corn in the total production as a function of treatments

\begin{tabular}{|c|c|c|c|c|c|c|c|c|c|}
\hline \multirow{3}{*}{ Treatment } & \multicolumn{3}{|c|}{ Soybean } & \multicolumn{6}{|c|}{ Corn } \\
\hline & $\overline{\mathrm{LS}}$ & SS & PS & LS & SS & PS & $\mathrm{SM}$ & LS & SS \\
\hline & \multicolumn{3}{|c|}{$\mathrm{g} \mathrm{kg}^{-1} \mathrm{DM}$} & \multicolumn{6}{|c|}{$\mathrm{g} \mathrm{kg}^{-1} \mathrm{DM}$} \\
\hline $\mathrm{IN}+20 \mathrm{~S}$ & $4.2 \mathrm{~b}^{1 /}$ & $13.9 \mathrm{~b}$ & $20.8 \mathrm{~b}$ & $8.3^{2 /}$ & 241.6 & 127.9 & 87.6 & 381.3 & 114.4 \\
\hline $\mathrm{IN}+20 \mathrm{~S}+30 \mathrm{~V}_{4}$ & $6.7 \mathrm{~b}$ & $23.5 \mathrm{~b}$ & $27.3 \mathrm{~b}$ & 8.4 & 232.6 & 126.1 & 80.8 & 386.0 & 108.7 \\
\hline $\mathrm{IN}+20 \mathrm{~S}+60 \mathrm{~V}_{4}$ & $3.6 \mathrm{~b}$ & $13.5 \mathrm{~b}$ & $18.8 \mathrm{~b}$ & 7.9 & 237.5 & 123.4 & 79.1 & 414.9 & 101.3 \\
\hline $\mathrm{IN}+20 \mathrm{~S}+30 \mathrm{~V}_{4}+30 \mathrm{~V}_{7}$ & $5.6 \mathrm{~b}$ & $18.4 \mathrm{~b}$ & $23.4 \mathrm{~b}$ & 7.8 & 233.4 & 152.3 & 94.5 & 338.9 & 125.9 \\
\hline $\mathrm{IN}+20 \mathrm{~S}+120 \mathrm{~V}_{4}$ & $7.0 \mathrm{~b}$ & $17.4 \mathrm{~b}$ & $24.2 \mathrm{~b}$ & 6.7 & 238.0 & 89.6 & 80.7 & 421.1 & 115.3 \\
\hline $20 \mathrm{~S}+120 \mathrm{~V}_{4}$ & $8.4 \mathrm{~b}$ & $18.0 \mathrm{~b}$ & $16.1 \mathrm{~b}$ & 7.6 & 225.6 & 121.2 & 73.8 & 419.5 & 110.0 \\
\hline $20 \mathrm{~S}+60 \mathrm{~V}_{4}+60 \mathrm{~V}_{7}$ & $8.8 \mathrm{~b}$ & $12.8 \mathrm{~b}$ & $15.2 \mathrm{~b}$ & 6.7 & 232.5 & 126.2 & 79.6 & 421.6 & 96.6 \\
\hline $20 \mathrm{~S}+120 \mathrm{~V}_{4} *$ & $6.6 \mathrm{~b}$ & $19.3 \mathrm{~b}$ & $17.9 \mathrm{~b}$ & 6.5 & 237.8 & 122.3 & 79.3 & 402.3 & 108.0 \\
\hline $\mathrm{CM}$ & - & - & - & 7.2 & 287.4 & 133.6 & 76.6 & 392.1 & 103.1 \\
\hline SM & $222.8 \mathrm{a}$ & $280.3 \mathrm{a}$ & 496.9 a & - & - & - & - & - & - \\
\hline Mean & 30.4 & 46.3 & 73.4 & 7.5 & 240.7 & 124.7 & 81.3 & 397.5 & 109.3 \\
\hline CV (\%) & 33.76 & 25.46 & 31.63 & 18.48 & 17.95 & 16.48 & 10.17 & 15.43 & 21.41 \\
\hline
\end{tabular}

1/ Means followed by the same letter in the columns do not differ from each other by the Scott-Knott test $(\mathrm{p}<0.05) .{ }^{2 /}$ Not significant by the F-test. Treatments: IN = inoculation with Azospirillum brasilense in corn; $\mathrm{S}=$ nitrogen fertilization when sowing corn; $\mathrm{V}_{4}=$ topdressing nitrogen fertilization at the phenological stage $\mathrm{V}_{4}$ in corn; $\mathrm{V}_{7}=$ topdressing nitrogen fertilization at the phenological stage $\mathrm{V}_{7}$ in corn; $\mathrm{CM}=$ corn monoculture; $\mathrm{SM}=$ soybean monoculture; *broadcast fertilization; the numbers $20,30,60$, and 120 represent the applied amount of $\mathrm{N}\left(\mathrm{kg} \mathrm{ha}^{-1}\right)$.

No significant differences were observed between the corn-soybean intercropping treatments and corn monoculture for the components DM, CP, NDF, NFC, LIG, $\mathrm{MM}$, and $\mathrm{EE}$, demonstrating that the inclusion of intercropped soybean in the corn silage did not affect the values of these variables compared to standard corn silage (Table 3 ). 
Table 3. Contents of dry matter (DM), crude protein (CP), neutral detergent fiber (NDF), non-fibrous carbohydrates (CNF), lignin (LIG), mineral matter (MM), and ethereal extract (EE) in the silage from intercropped and monoculture treatments as a function of treatments

\begin{tabular}{lcccccccc}
\hline \multirow{2}{*}{ Treatment } & DM & CP & NDF & ADF & NFC & LIG & MM & EE \\
\cline { 2 - 10 } & $\%$ & & \multicolumn{7}{c}{$\%$ DM } \\
\hline $\mathrm{IN}+20 \mathrm{~S}$ & $35.55 \mathrm{a}^{1 /}$ & $9.70 \mathrm{a}$ & $36.74 \mathrm{a}$ & $22.15 \mathrm{~b}$ & $46.95 \mathrm{a}$ & $4.24 \mathrm{a}$ & $3.45 \mathrm{a}$ & $4.34 \mathrm{a}$ \\
$\mathrm{IN}+20 \mathrm{~S}+30 \mathrm{~V}_{4}$ & $34.89 \mathrm{a}$ & $9.88 \mathrm{a}$ & $40.61 \mathrm{a}$ & $22.87 \mathrm{~b}$ & $48.59 \mathrm{a}$ & $4.59 \mathrm{a}$ & $3.18 \mathrm{a}$ & $4.45 \mathrm{a}$ \\
$\mathrm{IN}+20 \mathrm{~S}+60 \mathrm{~V}_{4}$ & $35.46 \mathrm{a}$ & $9.49 \mathrm{a}$ & $36.77 \mathrm{a}$ & $21.53 \mathrm{~b}$ & $48.42 \mathrm{a}$ & $4.08 \mathrm{a}$ & $2.81 \mathrm{a}$ & $3.80 \mathrm{a}$ \\
$\mathrm{IN}+20 \mathrm{~S}+30 \mathrm{~V}_{4}+30 \mathrm{~V}_{7}$ & $34.31 \mathrm{a}$ & $9.13 \mathrm{a}$ & $36.33 \mathrm{a}$ & $21.06 \mathrm{c}$ & $49.12 \mathrm{a}$ & $4.24 \mathrm{a}$ & $3.12 \mathrm{a}$ & $4.31 \mathrm{a}$ \\
$\mathrm{IN}+20 \mathrm{~S}+120 \mathrm{~V}_{4}$ & $33.83 \mathrm{a}$ & $9.29 \mathrm{a}$ & $35.42 \mathrm{a}$ & $20.42 \mathrm{c}$ & $50.14 \mathrm{a}$ & $4.18 \mathrm{a}$ & $3.01 \mathrm{a}$ & $3.70 \mathrm{a}$ \\
$20 \mathrm{~S}+120 \mathrm{~V}_{4}$ & $35.97 \mathrm{a}$ & $9.33 \mathrm{a}$ & $35.94 \mathrm{a}$ & $20.16 \mathrm{c}$ & $47.25 \mathrm{a}$ & $4.16 \mathrm{a}$ & $2.87 \mathrm{a}$ & $4.56 \mathrm{a}$ \\
$20 \mathrm{~S}+60 \mathrm{~V}_{4}+60 \mathrm{~V}_{7}$ & $35.34 \mathrm{a}$ & $9.35 \mathrm{a}$ & $39.66 \mathrm{a}$ & $20.83 \mathrm{c}$ & $47.97 \mathrm{a}$ & $4.04 \mathrm{a}$ & $3.20 \mathrm{a}$ & $4.12 \mathrm{a}$ \\
$20 \mathrm{~S}+120 \mathrm{~V}_{4} *$ & $34.74 \mathrm{a}$ & $9.24 \mathrm{a}$ & $36.81 \mathrm{a}$ & $19.06 \mathrm{c}$ & $49.29 \mathrm{a}$ & $3.90 \mathrm{a}$ & $2.99 \mathrm{a}$ & $3.72 \mathrm{a}$ \\
$\mathrm{CM}$ & $36.25 \mathrm{a}$ & $8.73 \mathrm{a}$ & $38.65 \mathrm{a}$ & $20.30 \mathrm{c}$ & $48.0 \mathrm{a}$ & $4.16 \mathrm{a}$ & $2.89 \mathrm{a}$ & $4.12 \mathrm{a}$ \\
$\mathrm{SM}$ & $25.67 \mathrm{~b}$ & $24.36 \mathrm{~b}$ & $37.21 \mathrm{~b}$ & $25.90 \mathrm{a}$ & $34.71 \mathrm{~b}$ & $4.74 \mathrm{~b}$ & $5.58 \mathrm{~b}$ & $9.66 \mathrm{~b}$ \\
\hline \multicolumn{1}{c}{ Mean } & 34.20 & 10.85 & 37.41 & 21.43 & 47.04 & 4.23 & 3.31 & 4.68 \\
\hline \multicolumn{1}{c}{$\mathrm{CV}(\%)$} & 5.82 & 4.84 & 7.86 & 5.11 & 4.06 & 18.00 & 17.68 & 14.91
\end{tabular}

${ }^{1 /}$ Means followed by the same letter in the columns do not differ from each other by the Scott-Knott test $(\mathrm{p}<0.05)$. Treatments: $\mathrm{IN}=$ inoculation with Azospirillum brasilense in corn; $\mathrm{S}=$ nitrogen fertilization when sowing corn; $\mathrm{V}_{4}=$ topdressing nitrogen fertilization at the phenological stage $\mathrm{V}_{4}$ in corn; $\mathrm{V}_{7}=$ topdressing nitrogen fertilization at the phenological stage $\mathrm{V}_{7}$ in corn; $\mathrm{CM}=$ corn monoculture; $\mathrm{SM}=$ soybean monoculture; *broadcast fertilization; the numbers 20,30,60, and 120 represent the applied amount of $\mathrm{N}$ $\left(\mathrm{kg} \mathrm{ha}^{-1}\right)$.

Studies have shown an increase in PB contents in silage from intercropping corn and soybean compared to corn monoculture, which is dependent on edaphoclimatic and management factors of this intercropping (MARTIN et al., 1998; DU et al., 2017, BATISTA et al., 2018; BATISTA et al., 2019). Batista et al. (2019) evaluated cultivation systems between corn and soybean plants and found that the spatial arrangements of two corn rows + two soybean rows and four corn rows + four soybean rows alternated on intercropping resulted in an increased CP compared to corn monoculture. Batista et al. (2018) tested the intercropping between early-cycle and medium-cycle corn hybrids and soybean varieties from different groups of relative maturation (5.1 and 6.2) and observed increases in CP contents in the ensiled mass compared to the silage of corn monocultures. Regarding the soybean varieties used for intercropping corn, Martin et al. (1998) pointed out that the use of late-cycle varieties resulted in an increase in $\mathrm{CP}$ concentration of the ensiled mass in the intercropping compared to corn monoculture and that the cycle extension allowed the soybean plant to be harvested green enough, avoiding the minimum losses with pod 
breakage at the ensiling time. Soybean monoculture showed lower DM, NDF, and NFC values and higher PB, LIG, $\mathrm{MM}$, and EE values (Table 3) than silages containing corn associated or not with soybean. According to Gobetti et al. (2011), the soybean harvested for silage production at the $\mathrm{R} 5$ stage tends to present $\mathrm{CP}$ values of approximately $18 \%$ $\mathrm{DM}$, but results above this value were found in this research.

According to Van Soest (1994), ADF is directly related to the food digestibility, being mostly composed of lignin and cellulose. The soybean monoculture showed higher ADF values, which is common for legumes, as they present a good digestibility due to the high $\mathrm{CP}$ contents and low LIG:NDF ratio. Treatments with the inoculant associated with lower topdressing $\mathrm{N}$ doses $(\mathrm{IN}+20 \mathrm{~S}, \quad \mathrm{IN}+20 \mathrm{~S}+30 \mathrm{~V} 4, \quad$ and $\mathrm{IN}+20 \mathrm{~S}+60 \mathrm{~V} 4)$ presented higher $\mathrm{ADF}$ values than the other intercropped cultivations. Despite this, the IVDMD values were higher (Table 4). Even though no statistical differences were observed in the proportions of soybean organs in the ensiled mass in treatments with higher $\mathrm{N}$ supply and absence of coexistence with soybean, the best development of the corn plant that uses $\mathrm{N}$ better for its growth may have contributed to the lowest ADF values (Table 3).

The potential of a plant for ensiling is dependent on the original moisture content, soluble carbohydrates content (above $8 \% \mathrm{DM}$ ), and low buffering power, which should not offer resistance to reducing the $\mathrm{pH}$ to values between 3.8 and 4.0 to preserve the silage nutrients as much as possible (Mc DONALD et al., 1991). In the present study, the DM content of treatments with corn at the time of the $35 \%$ ensilage was close to the value recommended by these authors. 
Table 4. Digestible energy (DE), metabolizable energy (ME), net energy (NE), total digestible nutrients (TDN), in vitro dry matter digestibility (IVDMD), temperature (TEM), and $\mathrm{pH}$ in the silage from intercropped and monoculture treatments as a function of treatments

\begin{tabular}{|c|c|c|c|c|c|c|c|}
\hline \multirow{2}{*}{ Treatment } & $\mathrm{DE}$ & $\mathrm{ME}$ & $\mathrm{NE}$ & TDN & IVDMD & TEMP & $\mathrm{pH}$ \\
\hline & \multicolumn{3}{|c|}{ Mcal kg-1 } & $\%$ & $\%$ & ${ }^{\circ} \mathrm{C}$ & $\mathrm{mol} \mathrm{L}^{-1}$ \\
\hline $\mathrm{IN}+20 \mathrm{~S}$ & $84.39 \mathrm{a}^{1 /}$ & $84.12 \mathrm{a}$ & $2.21 \mathrm{a}$ & $84.39 \mathrm{a}$ & $78.15 \mathrm{~b}$ & $26.20^{2 /}$ & $3.60 \mathrm{a}$ \\
\hline $\mathrm{IN}+20 \mathrm{~S}+30 \mathrm{~V}_{4}$ & 89.99 a & $89.99 \mathrm{a}$ & $2.27 \mathrm{a}$ & $89.99 \mathrm{a}$ & $77.93 \mathrm{~b}$ & 25.80 & $3.71 \mathrm{a}$ \\
\hline $\mathrm{IN}+20 \mathrm{~S}+60 \mathrm{~V}_{4}$ & $85.09 \mathrm{a}$ & $85.09 \mathrm{a}$ & $2.14 \mathrm{a}$ & $85.09 \mathrm{a}$ & $75.93 \mathrm{~b}$ & 25.85 & $3.68 \mathrm{a}$ \\
\hline $\mathrm{IN}+20 \mathrm{~S}+30 \mathrm{~V}_{4}+30 \mathrm{~V}_{7}$ & $85.82 \mathrm{a}$ & $85.82 \mathrm{a}$ & $2.16 \mathrm{a}$ & $85.82 \mathrm{a}$ & $74.51 \mathrm{a}$ & 25.75 & $3.88 \mathrm{a}$ \\
\hline $\mathrm{IN}+20 \mathrm{~S}+120 \mathrm{~V}_{4}$ & $85.76 \mathrm{a}$ & $85.76 \mathrm{a}$ & $2.16 \mathrm{a}$ & $85.76 \mathrm{a}$ & $73.02 \mathrm{a}$ & 25.85 & $3.68 \mathrm{a}$ \\
\hline $20 \mathrm{~S}+120 \mathrm{~V}_{4}$ & $84.12 \mathrm{a}$ & $84.12 \mathrm{a}$ & $2.11 \mathrm{a}$ & $84.12 \mathrm{a}$ & $74.40 \mathrm{a}$ & 25.55 & $3.65 \mathrm{a}$ \\
\hline $20 \mathrm{~S}+60 \mathrm{~V}_{4}+60 \mathrm{~V}_{7}$ & $87.88 \mathrm{a}$ & $87.88 \mathrm{a}$ & $2.21 \mathrm{a}$ & $87.88 \mathrm{a}$ & $73.12 \mathrm{a}$ & 25.95 & $3.71 \mathrm{a}$ \\
\hline $20 \mathrm{~S}+120 \mathrm{~V}_{4} *$ & $86.00 \mathrm{a}$ & $86.00 \mathrm{a}$ & $2.16 \mathrm{a}$ & $86.00 \mathrm{a}$ & $73.54 \mathrm{a}$ & 25.75 & $3.68 \mathrm{a}$ \\
\hline $\mathrm{CM}$ & $86.70 \mathrm{a}$ & $86.70 \mathrm{a}$ & $2.18 \mathrm{a}$ & $86.70 \mathrm{a}$ & $74.04 \mathrm{a}$ & 25.70 & $3.66 \mathrm{a}$ \\
\hline SM & $75.25 \mathrm{~b}$ & $75.25 \mathrm{~b}$ & $1.88 \mathrm{~b}$ & $75.25 \mathrm{~b}$ & $77.29 b$ & 25.30 & $5.07 \mathrm{~b}$ \\
\hline Mean & 85.10 & 85.07 & 2.15 & 85.10 & 75.19 & 25.72 & 3.83 \\
\hline $\mathrm{CV}(\%)$ & 4.64 & 5.23 & 4.87 & 4.61 & 2.50 & 1.41 & 5.69 \\
\hline
\end{tabular}

1/ Means followed by the same letter in the columns do not differ from each other by the Scott-Knott test $(\mathrm{p}<0.05) .{ }^{2 /}$ Not significant by the F-test. Treatments: IN = inoculation with Azospirillum brasilense in corn; $\mathrm{S}=$ nitrogen fertilization when sowing corn; $\mathrm{V}_{4}=$ topdressing nitrogen fertilization at the phenological stage $\mathrm{V}_{4}$ in corn; $\mathrm{V}_{7}=$ topdressing nitrogen fertilization at the phenological stage $\mathrm{V}_{7}$ in corn; $\mathrm{CM}=$ corn monoculture; $\mathrm{SM}=$ soybean monoculture; *broadcast fertilization; the numbers $20,30,60$, and 120 represent the applied amount of $\mathrm{N}\left(\mathrm{kg} \mathrm{ha}^{-1}\right)$.

The values of the total digestible nutrients (TDN), net energy (NE), metabolized energy (ME), and digestible energy (DE) showed no alterations for the silage from intercropping (Table 4). It was due to the lack of effects of fertilizer levels on the nutrient contents that are used for the calculations.

The IVDMD values were higher for the treatments IN+20S, IN+20S+30V4, and IN+20S+60V4 (Table 4), as observed for the ADF values (Table 3 ). On the other hand, even in the absence of statistical differences for the proportion of pods (Table 2) and CP (Table 3), the presented values may have resulted in a better substrate for microbial fermentation in these treatments. Van Soest (1994) mentioned that $\mathrm{N}$ causes an increase in the concentration of amino acids and proteins, which are accumulated mainly in the cell content, causing dilution of the cell wall and increased digestibility. However, it can be counterbalanced by 
the increased wall lignification in the presence of nitrogen fertilization suitable for good plant growth. According to these factors, this author mentioned that changes in digestibility of all types, attributed to nitrogen fertilization, have been reported, but the trend is to reduce IVDMD slightly.

No statistical differences were observed for the $\mathrm{pH}$ in treatments that included corn in the silage. They were lower than the $\mathrm{pH}$ of the soybean monoculture silage due to the higher NFC contents in these treatments (Table 4), which favored the silage fermentation profile. Heinritz et al. (2012) and Lima-Orozco et al. (2012) stated that legume silages are stabilized in higher $\mathrm{pH}$ ranges, as observed in this study. The increased $\mathrm{pH}$ in the soybean silage occurred mainly due to the increased buffering power caused by proteolysis, releasing ammonia, which has a basic character and makes it difficult to drop the $\mathrm{pH}$. A $\mathrm{pH}$ reduction needs to be achieved quickly to prevent the activity of undesirable microorganisms, especially enterobacteria and clostridia.

The temperature values showed no effects of treatments (Table 4). Barbosa et al. (2011) worked with the aerobic stability of monoculture and intercropped corn and soybean silage and found average temperature values of $24.43{ }^{\circ} \mathrm{C}$ for soybean monoculture silage and 24 to $25^{\circ} \mathrm{C}$ for intercropped corn and soybean silage, corroborating the values obtained in the present study.

The contents of acetic (AA), butyric (BA), lactic (LA), and propionic acid (PA) of the silage showed no statistical differences between treatments (Table 5). In this case, the treatments with corn presented no significant differences in the nutritional components (Table 3). 
Table 5. Contents of acetic (AA), butyric (BA), lactic (LA), and propionic acid (PA) in the silage of the intercropped and monoculture treatments as a function of treatments

\begin{tabular}{lccccc}
\hline \multirow{2}{*}{ Treatments } & AA & BA & LA & PA & $\mathrm{NH}_{3}$ \\
\cline { 2 - 6 } & \multicolumn{5}{c}{$\mathrm{Mg} \mathrm{dL}^{-1}$} \\
\hline $\mathrm{IN}+20 \mathrm{~S}$ & $3.46^{1 /}$ & 0.060 & 3.46 & 1.35 & $0.237 \mathrm{~b}^{2 /}$ \\
$\mathrm{IN}+20 \mathrm{~S}+30 \mathrm{~V}_{4}$ & 2.58 & 0.067 & 2.58 & 1.33 & $0.269 \mathrm{~b}$ \\
$\mathrm{IN}+20 \mathrm{~S}+60 \mathrm{~V}_{4}$ & 2.63 & 0.065 & 2.63 & 1.50 & $0.302 \mathrm{~b}$ \\
$\mathrm{IN}+20 \mathrm{~S}+30 \mathrm{~V}_{4}+30 \mathrm{~V}_{7}$ & 3.29 & 0.062 & 3.29 & 1.39 & $0.278 \mathrm{~b}$ \\
$\mathrm{IN}+20 \mathrm{~S}+120 \mathrm{~V}_{4}$ & 2.22 & 0.067 & 2.22 & 1.13 & $0.201 \mathrm{~b}$ \\
$20 \mathrm{~S}+120 \mathrm{~V}_{4}$ & 3.26 & 0.077 & 3.26 & 1.34 & $0.217 \mathrm{~b}$ \\
$20 \mathrm{~S}+60 \mathrm{~V}_{4}+60 \mathrm{~V}_{7}$ & 2.97 & 0.077 & 2.97 & 1.57 & $0.260 \mathrm{~b}$ \\
$20 \mathrm{~S}+120 \mathrm{~V}_{4} *$ & 2.80 & 0.070 & 2.80 & 1.29 & $0.176 \mathrm{~b}$ \\
$\mathrm{CM}$ & 3.19 & 0.067 & 3.19 & 1.48 & $0.154 \mathrm{~b}$ \\
$\mathrm{SM}$ & 4.92 & 0.057 & 4.82 & 1.89 & $8.009 \mathrm{a}$ \\
\hline \multicolumn{1}{c}{ Mean } & 3.13 & 0.067 & 3.12 & 1.43 & 1.096 \\
\hline \multicolumn{1}{c}{$\mathrm{CV}(\%)$} & 44.08 & 16.82 & 44.08 & 53.40 & 26.46
\end{tabular}

1/ Not significant by the F-test. ${ }^{2 /}$ Means followed by the same letter in the columns do not differ from each other by the Scott-Knott test $(\mathrm{p}<0.05)$. Treatments: $\mathrm{IN}=$ inoculation with Azospirillum brasilense in corn; $\mathrm{S}=$ nitrogen fertilization when sowing corn; $\mathrm{V}_{4}=$ topdressing nitrogen fertilization at the phenological stage $\mathrm{V}_{4}$ in corn; $\mathrm{V}_{7}=$ topdressing nitrogen fertilization at the phenological stage $\mathrm{V}_{7}$ in corn; $\mathrm{CM}=$ corn monoculture; $\mathrm{SM}=$ soybean monoculture; *broadcast fertilization; the numbers 20, 30, 60, and 120 represent the applied amount of $\mathrm{N}\left(\mathrm{kg} \mathrm{ha}^{-1}\right)$.

The main substrate for the formation of organic acids is NFC, which showed similar values in all treatments. However, the fatty acid evaluations of the experimental units (Table 5) showed no statistical difference because the fermentation process was stabilized at the time of sample collection. Moreover, higher $\mathrm{NH}_{3}$ values were observed for the soybean monoculture due to the higher $\mathrm{N}$ content in soybean plants.

In summary, inoculation with $A$. brasilense in corn intercropped with soybean and treated with the lowest $\mathrm{N}$ doses provided higher ADF and IVDMD contents in the mixed silage. The bromatological composition, digestibility, $\mathrm{pH}$, energy content, and profiles of organic acid in the silage were not altered by treatments.

\section{ACKNOWLEDGMENTS}

To the National Council for Scientific and Technological Development (CNPq) and the Fundação de Amparo à Pesquisa do Estado de Goiás (FAPEG) for the financial support.

\section{REFERENCES}

ASSOCIATION OF OFFICIAL ANALYTICAL CHEMISTS. Official methods of association of official 
analytical chemists. 15 .ed.

Washington: AOAC, 1990. 684p.

BARBOSA, L.A.; REZENDE, A.V.; RABELO, C.H.; RABELO, F.H.; NOGUEIRA, D.A. Estabilidade aeróbica de silagens de milho e soja exclusivas ou associadas. Ars.

Veterinaria, v.27, n.4, p.255-262, 2011.

BATISTA, V.V.; ADAMI, P.F., MORAES, P.V.D.; OLIGINI, K.F.; GIACOMEL, C.L.; LINK, L. Row arrangements of maize and soybean intercrop on silage quality and grain yield. Journal of Agricultural Science, v.11, n.2, p. 286-300, 2019.

BATISTA, V.V.; ADAMI, P.F.; SARTOR, L.R.; SILVEIRA, M.F.; SOARES, A.B.; OLIGINI, K.F.; KWIECINSKI, D.; FERREIRA, M.L.; CAMANA, D.; GIACOMEL, C.L.; FONSECA, A.C. Forage yield and silage quality of intercropped maize+soybean with different relative maturity cycle. Journal of Agricultural Science; v.10, n.12, p.249-261, 2018.

CARDOSO, I.S.; JAKELAITIS, A.; MARQUES, K.O.; GUIMARÃES, K.C.; PEREIRA, L.S. Quality of silage produced from intercropped corn RR and soybeans RR. Bioscience Journal, v.35, n.6, p.1886-1898, 2019.

CHEN, P.; DU, Q.; LIU, X,; ZHOU, L.; HUSSAIN, S.; LEI, L.; SONG, C.; WANG, X,; LIU, W.; YANG, F.; SHU, K.; LIU, J.; DU, J.; YANG, W.; YONG, $\mathrm{T}$. Effects of reduced nitrogen inputs on crop yield and nitrogen use efficiency in a long term maize-soybean relay strip intercropping system. Plos One, v.12, n.9, e0184503, 2017.

CRUZ, S.C.S.; PEREIRA, F.D.S.; SANTOS, J.R. ALBUQUERQUE, A.W. PEREIRA, R.G. Adubação nitrogenada para o milho cultivado em sistema plantio direto, no Estado de Alagoas. Revista Brasileira de Engenharia Agrícola e Ambiental, v.12, n.1, p.62-68, 2008.

DU, J.B.; HAN, T.F.; GAI, J.Y.; YONG, T.W.; SUN, X.; WANG, X.C.; YANG, F.; LIU, J.; SHU, K.; LIU, W.G.; YANG, W.Y. Maize soybean strip intercropping: Achieved a balance between high productivity and sustainability. Journal of Integrative Agriculture, v.17, n.4, p.747-754, 2017.

GOBETTI, S.T.C.; NEUMANN, M.; OLIVEIRA, M.R.; OLIBONI, R. Produção e utilização da silagem de planta inteira de soja (Glycine max) para ruminantes. Ambiência, v.7, n.3, p.603-616, 2011.

HEINRITZ, S.N.; MARTENS, S.D.; AVILA, P.; HOEDTKEB, S. The effect of inoculant and sucrose addition on the silage quality of tropical forage legumes with varying ensilability. Animal Feed Science and Technology v.174, n.3, p.201-210, 2012.

LANA, M.C.; WOYTICHOSKI JÚNIOR, P.P.; LUCCA E BRACCINI, A.; SCAPIM, C. A.; RIZZATTI ÁVILA, M.; PAIOLA ALBRECHT, L. Arranjo espacial e adubação nitrogenada em cobertura na cultura do 
milho do milho. Acta Scientiarum

Agronomy, v.31, n.3, p.433-438, 2009.

LIMA-OROZCO, R.; CASTRO-

ALEGRÍA, A.; FIEVEZ, V. Ensiled sorghum and soybean as ruminant feed in the tropics, with emphasis on Cuba.

Grass Forage Science, v.68, n.1, p.2032. 2012.

LOPES, K.S.M.; FERNANDES, J.; YOKOBATAKE, K.L.A.; LAZARINI, E.; PEREIRA NETO, A.C.; SANTOS, M.P.; COSTA, N.R.; LOPES, K.S.M.; ANDREOTTI, M. Composição bromatológica de silagens de grão úmido de soja com diferentes teores de umidade. Tecnologia \& Ciência Agropecuária, v.8 n.5, p.51-58, 2014.

MARQUES, K.O.; JAKELAITIS, A.; GUIMARÃES, K.C.; PEREIRA, L.S.; CARDOSO, I.S.; LIMA, S.F.

Production, fermentation profile, and nutritional quality of silage from corn and soybean intercropping. Semina:

Ciências Agrárias, v.40, n.6, Supl 2, p.3143-3156, 2019.

MARTIN, R.C.; ASTATKIE, T.; COOPER, J.M. The effect of soybean variety on corn-soybean intercrop biomass and protein yields. Canadian

Journal of Plant Science, v.78, n.2, p.289-294, 1998.

MCDONALD, P.; HENDERSON, A.R.; HERON, S.J.E. The biochemistry of silage. 2nd ed. Kent: Chalcombe Publications, 1991. 340p.

MENDES, I.C.; REIS JUNIOR, F.B.; HUNGRIA, M.; SOUSA, D.M.G.; CAMPO, R.J. Adubação nitrogenada suplementar tardia em soja cultivada em Latossolos do Cerrado. Pesquisa

Agropecuária Brasileira, v.43, n.8, p.1053-1060, 2008.

MOE, P.W.; FLATT, W.P.; TYRRELL, H.F. Net energy value of feeds for lactation. Journal of Dairy Science, v.55, n.7, p.945-958, 1972.

MORAES, S.D.; JOBIM, C.C.; SILVA, M.S.D.; MARQUARDT, F.S. Produção e composição química de híbridos de sorgo e de milho para silagem. Revista Brasileira de Saúde e Produção Animal, v.14, n.4, p.624-634, 2013.

NATIONAL RESEARCH COUNCIL NRC. Nutrient requirements of dairy cattle. 7th ed. Washington: National Academy Press, 2001. 381p.

PEREIRA, J.R.A.; ROSSI JR., P. Manual prático de avaliação de alimentos. Piracicaba: FEALQ. 1995, $34 \mathrm{p}$.

SANGINGA N.; WOOMER, P.L. Integrated soil fertility management in Africa: principles, practices and development process. Nairobi: IICTA, 2009, 263p.

SANTOS, E.M.; PEREIRA, O.G.; GARCIA, R.; FERREIRA, C.D.L.; OLIVEIRA, J.S.; SILVA, T.C.; ROSA, L.O. Microbial populations, fermentative profile and chemical composition of signalgrass silages at different regrowth ages. Revista Brasileira de Zootecnia, v.40, n.4, p.747-755, 2011. 
SANTOS, W.F.; AFFÉRRI, F.S.; PELÚZIO, J.M.; SODRÉ, L.F.; REINA, E.; PEREIRA, J.D.S.

Efficiency of nitrogen and genetic divergence in corn aiming for the production of protein. Journal of Bioenergy and Food Science, v.4, n.4, p.135-144, 2017.

SERAN, T.H.; BRINTHA, I. Review on maize based intercropping. Journal of Agronomy, v.9, n.3, p.135-145, 2010.

SILVA, A.R.; SALES, A.; VELOSO, C.A.C. Desenvolvimento da soja em sistemas de integração lavoura, pecuária-floresta. Enciclopédia Biosfera, v.11, n.22; p.896-904, 2015.

TILLEY, J.M.A.; TERRY, R.A. A twostage technique for the in vitro digestion of forage crops. Grass and Forage Science, v.18, n.2, p.104-111, 1963.

VAN SOEST, P.J.; ROBERTSON, J.B.; LEWIS, B.A. Methods for dietary fiber, neutral detergent fiber, and non-starch polysaccharides in relation to animal nutrition. Journal of Dairy Science. V.74, n.10, p.3583-3597, 1991.

VAN SOEST, P.J. Nutritional ecology of the ruminant. 2.ed. Ithaca: Cornell University Press, 1994. 476p.

YONG, T.; LIU, X.; YANG, F.; SONG, C.; WANG, X.; LIU, W.; SU, B.; ZHOU, L.; YANG, W. Characteristics of nitrogen uptake, use and transfer in a wheat-maize-soybean relay intercropping system. Plant Production Science, v.18, n.3, p.388-397, 2015.
ZOPOLLATTO, M.; NUSSIO, L.G.; MARI, L.J.; SCHMIDT, P.; DUARTE, A.P.; MOURÃO, G.B. Alterações na composição morfológica em função dos estágios de maturação em cultivares de milho para produção de silagem.

Revista Brasileira de Zootecnia, v.38, n.3, p.452-461, 2009. 